\title{
RELATIVE INDEX OF SUSCEPTIBILITY TO THE MAIZE WEEVIL, Sitophilus zeamais, AMONG SOME QPM CORN LINES
}

\author{
JAMILTON P. SANTOS ${ }^{1}$, PAULO E. O. GUIMARAES ${ }^{1}$, JOSÉ M. WAQUIL ${ }^{1}$ and JOHN E. FOSTER ${ }^{2}$ \\ ${ }^{1}$ Researchers of Embrapa Corn and Sorghum Research Center, Rodovia MG- 424 Km 65, 357001- 970, Sete Lagoas, \\ MG.Brazil,E-mail: jamilton@cnpms.embrapa.br; (author) \\ ${ }^{2}$ University of Nebraska, Lincoln, NE, 68583,E-mail: jfoster@unlnotes.unl.edu \\ Running Head: Santos et al. Relative Index of Susceptibility
}

Revista Brasileira de Milho e Sorgo, v.5, n.2, p.159-169, 2006

\begin{abstract}
The maize weevil, Sitophilus zeamais, is one important pest of stored corn grain. It is difficult to control and causes large weight and nutritional losses to the grains. The discovery of the gene Opaque-2 (O-2) that enhances the protein quality with Lysine and Tryptophane opened new perspectives to use corn to feed monogastric animals and for human nutrition. However, the soft and farinaceous consistency of the endosperm in the O-2 gene corn increased the susceptibility to maize weevil. To solve this problem the O-2 gene was transferred to normal corn. This new corn was called Quality Protein Maize (QPM). The objective of this study was to evaluate a selected group of corn genotypes for genetic resistance to maize weevil. A parameter named Index of Susceptibility (IS), which considers the progeny number in the F1 generation and the time the insects take to mature from egg to adult was used to measure the susceptibility. Some genotypes had an IS close to resistant control (such as the Cateto-SL, a very hard flint endosperm grain), but some had an IS like the susceptible control. This is an evidence of genetic variability within the QPM genotypes for resistance to maize weevil. It is reported the discovery of a group of experimental QPM hybrids and lines that carry genes for resistance to maize weevil. Also, it is possible to say that the QPM is not necessarily more susceptible to maize weevil damage than it is the normal endosperm type of the commercial corn available on the market.
\end{abstract}

Key words: Genetic resistance, stored grain pest, QPM corn

\section{INDICE DE SUSCEPTIBILIDADE RELATIVA AO GORGULHO DO MILHO, Sitophilus zeamais, EM UM GRUPO ELITE DE MILHOS QPM}

RESUMO - O gorgulho do milho, Sitophilus zeamais, é uma importante praga do milho armazenado. É de difícil controle e causa grandes perdas de peso e nutricionais aos grãos. A descoberta do gene Opaco-2 $\left(\mathrm{O}_{2}\right)$, que enriquece qualitativamete a proteína com os aminoácidos essenciais lysina e tryptofano, abriu novas perspectivas para se usar o milho tanto na alimentação de animais monogástricos como de pessoas. Entretanto, a consistência macia e farinácea do endosperma do grão portador do gene $\mathrm{O}_{2}$ aumentou a susceptibilidade ao gorgulho. Para solucionar este problema, o gene $\mathrm{O}_{2}$ foi transferido para linhagens de milho com endosperma normal. Esse novo milho foi denominado de Quality Protein Mayze (QPM). O objetivo desta pesquisa foi avaliar um grupo elite de genótipos para resistência genética do grão ao gorgulho. O parâmetro definido como 
Índice de Susceptibilidade (IS), que considera o número da prole da geração F1 e tempo de duração do ciclo biológico, foi usado para medir a susceptibilidade. Os resultados indicaram que alguns genótipos QPM tiveram o valor do IS próximo da testemunha resistente, o milho Cateto SL, com endosperma flint e duro, mas outros genótipos QPM tiveram IS como o da testemunha susceptível, o IAC 1- $\mathrm{O}_{2}$ Esta é, portanto, uma evidência da variabilidade genética para resistência ao gorgulho dentro desse grupo elite de genótipos QPM, considerando com a descoberta de híbridos experimentais e linhagens QPM portadores de genes para resistência ao gorgulho. Também, com base nos resultados obtidos, é possível afirmar que os genótipos QPM não são, necessariamente, sempre mais susceptíveis a sofrer maiores danos pelo gorgulho do que os genótipos dos milhos chamados normais, comercialmente à disposição no mercado.

Palavras-chave: Resistência genética, pragas grãos armazenados, milho QPM

Corn is the most widely grown grain crop in Brazil, occupying more than 12 million hectares. Most of the grain is used as animal feed, but a significant percentage of it goes to human consumption. Grain storage remains a problem. The maize weevil, Sitophilus zeamais, has long been considered one of the most important pests of stored corn grain, especially in the tropics (Genel 1960, Koura and El-Halfaway, 1967 and Rossetto, 1972). This insect causes great reductions in the nutritional value of the grain (Irabagon 1959; Vilela et al. 1988), death to the embryo with consequent loss of germination (Santos et al., 1990), \& damage of 17.3, 36.4 and 44.5 percent of the grains, as observed in a survey on corn stored with the husk at 3,6, and 9 months after harvest (Santos and Fontes, 1990). These authors also observed that a single larva caused 18 percent weight loss to a single kernel.

Mertz et al. (1964) reported the discovery of a corn type with the Opaque-2 (O-2), a mutant gene that changes the protein composition and increases the content of lysine and tryptophan, in the maize endosperm. However, the endosperm of the O-2 gene corn was found to be light and soft (Dimler, 1966). The softness of the endosperm causes O-2 maize to be very attractive to the stored grain pest (Wheatley, 1973 and Ortega 1975). To solve this problem, researchers in RESISTENCIA, Mexico, transferred the O-2 gene to corn with normal kernels. This new type of maize was called Quality Protein Maize (QPM). Additional breeding selections made at the National Maize and Sorghum Research Center (Centro Nacional de Pesquisa de Milho e SorgoCNPMS) of EMBRAPA (Empresa Brasileira de Pesquisa Agropecuária) and Ministry of Agriculture Livestock and Food Supply, in Brazil, produced some white and yellow color QPM lines and/or hybrids.

Maize breeders have released many new lines and hybrids but so much emphasis has been put in quantitative production. Only more recently attention started turning to quality. One example is the release of the BR-451, a QPM white line. The white color relates to the possibility of substituting 30 percent of the wheat flour in the bread industry, enriching the nutritious quality of the bread and decreasing the price. Research with the BR-451 showed that it is less preferred by the maize weevil than the corn with the O-2 gene; but it is still more preferred by this pest than some of the available commercial hybrids. Thus, it is necessary to improve the genetic resistance to 
maize weevil in the QPM lines in order to prevent excessive insect infestation that may damage the grain.

Many different approaches have been used to evaluate grain for resistance to insects. One procedure involved the evaluation of the first generation of adult insects that emerged from a given number of parents, in a way that the females were allowed to oviposit for a determined period of time. Another method is the evaluation of grain weight loss when a grain sample is highly infested for a prolonged period of time. One technique which seems to be very appropriate for measuring susceptibility was described by Wheatley (1973), and also reported and named by Dobie (1974), as Index of Susceptibility (IS). This method is based on the number of progeny from the first generation of insects emerged after a set of females were allowed to oviposit for a fixed number of days on test material and on the developmental period (egg to adult) of this progeny. The objective of this study was to evaluate a selected group of QPM experimental lines and hybrids, plus several commercial hybrids for genetic resistance to the maize weevil.

\section{Material and Methods}

This research was conducted at the CNPMS, an EMBRAPA/Ministry of Agriculture institution, located in Sete Lagoas, MG, Brazil. Two entries, Cateto- SL and IAC- I O2 IV, were obtained from the germplasm stock, and twenty three entries with the QPM genetic background came from the CNPMS breeding program. Three entries, BR-201(hybrid), and BR-106 and BR451(lines) are material released by Embrapa/ CNPMS for commercial planting, and the AG122, AG-510 and C-805 are hybrids sold by private companies. The QPM tested in this research are all experimental material except the
BR-451. The entries Cateto-SL and the IAC-I O2 IV are considered, respectively, resistant and susceptible according to previous work (Santos, 1977). They were included in this study to make possible relative comparisons. Some commercial hybrids were also included to observe what would be the potential for the QPM material to compete with those available on the market, as far as damage suffered from insects during storage is concerned.

The description and identification of all genotypes tested are shown in Table 1.

The seed samples, which had never been treated with insecticide, were placed in the freezer $\left(-15^{\circ} \mathrm{C}\right)$ for five days to eliminate any insect infestation. The insects that were used came from a $S$. zeamais laboratory culture maintained in controlled conditions ( $70 \%$ R.H. and $27 \pm 0.5^{\circ} \mathrm{C}$ ). The species was confirmed according to the aedegus characteristics as described by Halstead (1962). Neonate to 5-day-old insects were placed in a small sample of each tested entry to allow them to adjust to the new food source and oviposition site on the experimental materials. The methodology used to measure susceptibility was based on the work done by Dobie (1974) and is summarized as follows. The moisture content of the grains was adjusted to $13.5 \%( \pm 1 \%)$ and three replicates of 200 grains from each genotype were produced. Twenty females and ten males of maize weevil, 10 to 15 days old, were used to infest each replicate at $27 \pm 1^{\circ} \mathrm{C}$ and $70 \%$ R.H., and $12 \mathrm{hrs}$ photoperiod. After an oviposition period of 10 days, the parents were discarded, and the tested genotypes were left undisturbed until the progeny started to emerge, in 32 days. The insects were removed every other day until all F1 emerged. The total number of $F_{1}$ insects and the mean development period were obtained for each replicate. 
TABLE 1. Identification of genotypes tested for genetic resistance to maize weevil.

\begin{tabular}{|c|c|c|c|c|}
\hline ORDER & NAME & ENDOSPERM & COLOR & SELECTION CYCLE \\
\hline 01 & Cateto-Sete Lagoas & Normal & Yellow & No selection \\
\hline 02 & IAC-1 O2 IV & Opaque - 2 & White & No selection \\
\hline 03 & 92 HD - 1 & QPM & Yellow & First sib \\
\hline 04 & $93 \mathrm{HD}-1$ & QPM & Yellow & “ \\
\hline 05 & $93 \mathrm{HD}-3$ & QPM & Yellow & $"$ \\
\hline 06 & $93 \mathrm{HD}-5$ & QPM & Yellow & “ \\
\hline 07 & $93 \mathrm{HD}-6$ & QPM & Yellow & $"$ \\
\hline 08 & $93 \mathrm{HD}-12$ & QPM & Yellow & “ \\
\hline 09 & $93 \mathrm{HT}-11$ & QPM & Yellow & Second sib \\
\hline 10 & $93 \mathrm{HT}-12$ & QPM & Yellow & “ \\
\hline 11 & $93 \mathrm{HT}-14$ & QPM & Yellow & $"$ \\
\hline 12 & $93 \mathrm{HT}-17$ & QPM & Yellow & “ \\
\hline 13 & 93 HT - 18 & QPM & Yellow & $"$ \\
\hline 14 & $93 \mathrm{HT}-23$ & QPM & Yellow & “ \\
\hline 15 & $93 \mathrm{HT}-24$ & QPM & Yellow & $"$ \\
\hline 16 & $92 \mathrm{HD}-04$ & QPM & Yellow & Third sib \\
\hline 17 & $93 \mathrm{HD}-20$ & QPM & Yellow & “ \\
\hline 18 & 93 HD - 26 & QPM & Yellow & $"$ \\
\hline 19 & 93 HT - 27 & QPM & Yellow & “ \\
\hline 20 & $93 \mathrm{HT}-28$ & QPM & Yellow & $"$ \\
\hline 21 & $93 \mathrm{HT}-30$ & QPM & Yellow & “ \\
\hline 22 & HT - 2X & QPM & Yellow & $”$ \\
\hline 23 & CMS - $455 \mathrm{CE}$ & QPM & Yellow & Pre-release \\
\hline 24 & CMS - 455 & QPM & Yellow & Pre-release \\
\hline 25 & SYNTETIC & QPM & Yellow & Pre-release \\
\hline 26 & BR - 451 & QPM & White & Commercial \\
\hline 27 & BR - 106 & NORMAL & Yellow & Commercial \\
\hline 28 & BR - 201 & NORMAL & Yellow & Commercial \\
\hline 29 & AG -122 & NORMAL & Yellow & Commercial \\
\hline 30 & $A G-510$ & NORMAL & Yellow & Commercial \\
\hline 31 & CA -805 & NORMAL & Yellow & Commercial \\
\hline
\end{tabular}


The parameter derived from the procedure described above is the IS and defined as:

$\mathrm{MDP}=\frac{\Sigma(\mathrm{x}, \mathrm{y}) \log e}{\Sigma \mathrm{X}}, \quad$ and $\quad \mathrm{IS}=\frac{\Sigma \mathrm{x}}{\mathrm{MDP}} \mathrm{X} 100$

Where:

Period

MDP $=$ Mean of the Developmental

$\mathrm{x}=$ Number of insects emerged daily from the F1 generation

$y=$ Number of days from initial infestation to emergence of insects

IS = Index of Susceptibility

The statistical method followed a randomized complete block design and all data was submitted to an analysis of variance. The average mean was ranked by the Duncan's Multiple Range Test at the $a=0.05$ level of significance.

\section{Results and Discussion}

The Index of Susceptibility (IS) has been described in detail and found to be correlated with important genetic resistant factors like grain weight loss, number of F1 progeny, grain hardness, and rate of insect increase (Classen et al., 1990, Gomes et al., 1992). The antibiosis and nonpreference were observed acting together as mechanisms of resistance to the maize weevil in corn grain (Santos and Foster 1983), and they would possibly be responsible for the variation of the IS value.

In Table 2 it is possible to observe the variation of the mean progeny number of the F1 generation. The mean number of F1 progeny ranked from 60.4 for the genotype 93 HT-27 to 137.1 for the 93 HT-11. Some QPM genotypes produced equivalent number of insects to the resistant control, the Cateto- SL; however, some QPM genotypes produced as many insects as the susceptible control, the IAC 1-O2 IV. The mean number of insects produced by the commercial hybrids stayed around the overall mean. The larger the F1 progeny the heavier would be the infestation and the more susceptible is the genotype.

In Table 3 it is possible to observe the mean developmental period (MDP) of maize weevil in all genotypes tested. The MDP ranked from 45.64 for the genotype 93 HT-18 to 54.21 days for Cateto-SL. Some QPM genotypes had the MDP equivalent to the susceptible control and some to the resistant control. The MDP for the commercial hybrids, in general, stayed around the overall mean. A shorter MDP brings more generations a year and greater is the susceptibility of the genotype.

In Table 4 it is possible to see the IS to maize weevil for all genotypes tested. The higher the IS the more susceptible is the genotype. The IS value ranged from 7.58 for the Cateto- SL, which is the resistant control, to 10.73 for the 93 HT- 18, with the IS for the susceptible control being 10.50. Eight QPM lines did not significantly differ from the resistant control but the other five QPM had IS which did not differ from the susceptible control either. One commercial hybrid, the AG - 122, did not differ from the resistant, but another, the CA - 805 did not differ from the susceptible.

The fact that some QPM lines had IS very close to the resistant control, Cateto-SL (a very hard flint endosperm maize), is a very significant result. It is one indication that some of the QPM corn hybrids tested, in addition to carrying genes for enhanced protein quality, also carry genes for resistance to maize weevil. One more significant 
TABLE 2. Mean number of maize weevil emerged from a ten-day oviposition period in some Quality Protein Maize (QPM) and some commercial hybrids tested for genetic resistance.

\begin{tabular}{|c|c|c|c|}
\hline ORDER & NAME & \multicolumn{2}{|c|}{ F1 PROGENY NUMBER ${ }^{1,2}$} \\
\hline 01 & $93 \mathrm{HT}-11 *$ & \multicolumn{2}{|c|}{$137.1 \mathrm{~A}$} \\
\hline 02 & IAC 1 - O2 IV*** & \multicolumn{2}{|c|}{$136.4 \mathrm{~A}$} \\
\hline 03 & $93 \mathrm{HT}-18^{*}$ & \multicolumn{2}{|c|}{$134.8 \mathrm{AB}$} \\
\hline 04 & $93 \mathrm{HD}-06^{*}$ & \multicolumn{2}{|c|}{$134.1 \mathrm{AB}$} \\
\hline 05 & $\mathrm{CA}-805^{* *}$ & \multicolumn{2}{|c|}{$128.8 \mathrm{ABC}$} \\
\hline 06 & 93 HD - $12 *$ & \multicolumn{2}{|c|}{$119.0 \mathrm{ABCD}$} \\
\hline 07 & $93 \mathrm{HT}-30^{*}$ & \multicolumn{2}{|c|}{ 115.8 ABCD } \\
\hline 08 & $93 \mathrm{HT}-24^{*}$ & \multicolumn{2}{|c|}{ 115.6 ABCD } \\
\hline 09 & $\mathrm{BR}-106^{* *}$ & \multicolumn{2}{|c|}{ 106.7 ABCDE } \\
\hline 10 & $93 \mathrm{HT}-12 *$ & \multicolumn{2}{|c|}{ 106.5 ABCDE } \\
\hline 11 & CMS $455 \mathrm{C}^{*}$ & \multicolumn{2}{|c|}{ 104.4 ABCDE } \\
\hline 12 & BR - 201** & \multicolumn{2}{|c|}{ 102.6 ABCDEF } \\
\hline 13 & $93 \mathrm{HD}-03 *$ & \multicolumn{2}{|c|}{ 102.4 ABCDEF } \\
\hline 14 & $92 \mathrm{HD}-01 *$ & \multicolumn{2}{|c|}{ 99.4 BCDEF } \\
\hline 15 & SYNTHETIC* & \multicolumn{2}{|c|}{ 96.0 CDEFG } \\
\hline 16 & $93 \mathrm{HT}-17^{*}$ & \multicolumn{2}{|c|}{ 94.1 CDEFG } \\
\hline 17 & $\mathrm{AG}-510 * *$ & \multicolumn{2}{|c|}{ 89.3 DEFGH } \\
\hline 18 & 93 HT - 23* & \multicolumn{2}{|c|}{88.3 DEFGHI } \\
\hline 19 & $\mathrm{BR}-451^{*}$ & \multicolumn{2}{|c|}{ 86.5 DEFGHI } \\
\hline 20 & $\mathrm{HT}-2 \mathrm{X}^{*}$ & \multicolumn{2}{|c|}{78.8 EFGHI } \\
\hline 21 & $93 \mathrm{HT}-28 *$ & \multicolumn{2}{|c|}{77.6 EFGHI } \\
\hline 22 & $\mathrm{AG}-122 * *$ & \multicolumn{2}{|c|}{$76.9 \quad$ EFGHI } \\
\hline 23 & $93 \mathrm{HD}-20 *$ & \multicolumn{2}{|c|}{$72.6 \quad$ FGHI } \\
\hline 24 & $93 \mathrm{HD}-26^{*}$ & \multicolumn{2}{|c|}{$72.3 \quad$ FGHI } \\
\hline 25 & CMS 455* & \multicolumn{2}{|c|}{$68.1 \quad$ GHI } \\
\hline 26 & $93 \mathrm{HD}-14^{*}$ & \multicolumn{2}{|l|}{64.2} \\
\hline 27 & CATETO -SL $* * * *$ & \multicolumn{2}{|l|}{62.0} \\
\hline 28 & $93 \mathrm{HD}-05^{*}$ & \multicolumn{2}{|l|}{61.9} \\
\hline 29 & $92 \mathrm{HD}-04^{*}$ & \multicolumn{2}{|l|}{61.5} \\
\hline 30 & $93 \mathrm{HD}-01 *$ & \multicolumn{2}{|l|}{61.5} \\
\hline 31 & $93 \mathrm{HT}-27$ & 60.4 & $\mathrm{I}$ \\
\hline
\end{tabular}

* QPM, ** Commercial *** Susceptible control **** Resistant control ${ }^{1}$ Means followed by the same letter do not differ significantly at a $=0.05$, according to the Duncan's Multiple Range Test.

${ }^{2}$ C.V. $=8.5 ; \mathrm{S}=0.48$ and $\mathrm{LSD}=1.38$ 
TABLE 3. Mean developmental period of maize weevil in some Quality Protein Maize (QPM) and some commercial hybrids tested for genetic resistance.

\begin{tabular}{|c|c|c|c|}
\hline ORDER & NAME & \multicolumn{2}{|c|}{ DEVELOPMENTAL PERIOD (days) ${ }^{1,2}$} \\
\hline 01 & CATETO - SL**** & \multicolumn{2}{|c|}{$54.21 \mathrm{~A}$} \\
\hline 02 & $93 \mathrm{HT}-27^{*}$ & \\
\hline 03 & CMS - 455* & \multicolumn{2}{|c|}{$\begin{array}{l}53.42 \mathrm{AB} \\
52.08 \mathrm{BC}\end{array}$} \\
\hline 04 & BR $-201 * *$ & \multicolumn{2}{|c|}{$51.90 \mathrm{BCD}$} \\
\hline 05 & $\mathrm{AG}-122 * *$ & \multicolumn{2}{|c|}{$51.72 \mathrm{BCD}$} \\
\hline 06 & $93 \mathrm{HD}-01^{*}$ & \multicolumn{2}{|c|}{51.72 BCD } \\
\hline 07 & $93 \mathrm{HD}-05^{*}$ & \multicolumn{2}{|c|}{$51.59 \mathrm{BCD}$} \\
\hline 08 & HT $-2 \mathrm{X} *$ & \multicolumn{2}{|c|}{$51.33 \mathrm{BCDE}$} \\
\hline 09 & $\mathrm{AG}-510^{* *}$ & \multicolumn{2}{|r|}{ CDEF } \\
\hline 10 & 93 HT - 28* & \multicolumn{2}{|r|}{ CDEF } \\
\hline 11 & $\mathrm{BR}-451^{*}$ & \multicolumn{2}{|c|}{50.77 CDEF } \\
\hline 12 & 92 HD - 04* & \multicolumn{2}{|r|}{ CDEFG } \\
\hline 13 & SYNTHETIC* & \multicolumn{2}{|r|}{ CDEFGH } \\
\hline 14 & $93 \mathrm{HT}-17 *$ & \multicolumn{2}{|r|}{ CDEFGHI } \\
\hline 15 & $93 \mathrm{HD}-26^{*}$ & \multicolumn{2}{|r|}{ CDEFGHI } \\
\hline 16 & $\mathrm{BR}-126^{* *}$ & \multicolumn{2}{|r|}{ CDEFGHI } \\
\hline 17 & 93 HT - 23* & \multicolumn{2}{|c|}{49.65 CDEFGHI } \\
\hline 18 & $93 \mathrm{HD}-14 *$ & \multicolumn{2}{|r|}{ DEFGHI } \\
\hline 19 & 93 HD - 03* & \multicolumn{2}{|r|}{ EFGHI } \\
\hline 20 & CA - $805^{* *}$ & \multicolumn{2}{|r|}{ EFGHI } \\
\hline 21 & $92 \mathrm{HD}-01 *$ & \multicolumn{2}{|r|}{ EFGHI } \\
\hline 22 & 93 HT - 12* & \multicolumn{2}{|r|}{ EFGHIJ } \\
\hline 23 & $93 \mathrm{HT}-30 *$ & \multicolumn{2}{|r|}{ FGHIJ } \\
\hline 24 & 93 HD - 06* & \multicolumn{2}{|r|}{ GHIJK } \\
\hline 25 & $93 \mathrm{HD}-20^{*}$ & \multicolumn{2}{|r|}{ HIJK } \\
\hline 26 & 93 HT - 24* & \multicolumn{2}{|r|}{ HIJKL } \\
\hline 27 & CMS - 455C* & \multicolumn{2}{|r|}{ HIJKL } \\
\hline 28 & 93 HT - 11* & \multicolumn{2}{|r|}{ IJKL } \\
\hline 29 & IAC $1-\mathrm{O} 2 \mathrm{IV}^{* * * *}$ & \multicolumn{2}{|l|}{46.67} \\
\hline 30 & 93 HD - 12* & 46.10 & $\mathrm{KL}$ \\
\hline 31 & $93 \mathrm{HT}-18 *$ & 45.64 & $\mathrm{~L}$ \\
\hline
\end{tabular}

* QPM **Commercial *** Susceptible check **** Resistant check

${ }^{1}$ Means followed by the same letter do not differ significantly at $\mathrm{a}=0.05$, according to Duncan's Multiple Range Test.

${ }^{2}$ C.V. $=8.5 ; \mathrm{S}=0.48$ and $\mathrm{LSD}=1.38$ 
TABLE 4. Index of Susceptibility (IS) of some Quality Protein Maize (QPM) and some commercial corn, tested for genetic resistance to maize weevil.

\begin{tabular}{|c|c|c|c|}
\hline ORDER & NAME & \multicolumn{2}{|c|}{ INDEX OF SUSCEPTIBILITY (IS) ${ }^{1,2}$} \\
\hline 01 & 93 НT-18* & \multicolumn{2}{|c|}{$10.73 \mathrm{~A}$} \\
\hline 02 & IAC-1 O2 IV*** & \multicolumn{2}{|c|}{$10.50 \mathrm{AB}$} \\
\hline 03 & 93 НT- $11 *$ & \multicolumn{2}{|c|}{$10.31 \mathrm{ABC}$} \\
\hline 04 & $93 \mathrm{HD}-12 *$ & \multicolumn{2}{|c|}{$10.29 \mathrm{ABCD}$} \\
\hline 05 & 93 HD - 06* & \multicolumn{2}{|c|}{$10.10 \mathrm{ABCDE}$} \\
\hline 06 & 93 HT - 24* & \multicolumn{2}{|c|}{ 09.88 ABCDEF } \\
\hline 07 & $\mathrm{CA}-805^{* *}$ & \\
\hline 08 & CMS 455C* & \multicolumn{2}{|c|}{$\begin{array}{l}09.84 \text { ABCDEF } \\
09.67 \quad \text { BCDEFG }\end{array}$} \\
\hline 09 & $93 \mathrm{HR}-30^{*}$ & \multicolumn{2}{|c|}{09.66 BCDEFG } \\
\hline 10 & 93 HT - 12* & \multicolumn{2}{|r|}{ CDEFGH } \\
\hline 11 & 93 HD - 03* & \multicolumn{2}{|r|}{ DEFGHI } \\
\hline 12 & 92 HD - 01* & \multicolumn{2}{|r|}{ EFGHI } \\
\hline 13 & BR - $106 * *$ & \multicolumn{2}{|r|}{ EFGHI } \\
\hline 14 & 93 HT $-17 *$ & \multicolumn{2}{|r|}{ FGHIJ } \\
\hline 15 & SYNTETIC* & \multicolumn{2}{|r|}{ FGHIJK } \\
\hline 16 & 93 HT - 23* & \multicolumn{2}{|r|}{ GHIJKL } \\
\hline 17 & $93 \mathrm{HD}-20^{*}$ & \multicolumn{2}{|r|}{ GHIJKL } \\
\hline 18 & BR - $201 * *$ & \multicolumn{2}{|r|}{ GHIJKLM } \\
\hline 19 & BR - $451^{*}$ & \multicolumn{2}{|r|}{ HIJKLMN } \\
\hline 20 & $\mathrm{AG}-510 * *$ & \multicolumn{2}{|r|}{ HIJKLMN } \\
\hline 21 & $93 \mathrm{HD}-26^{*}$ & \multicolumn{2}{|r|}{ IJKLMN } \\
\hline 22 & HT - $2 X^{*}$ & \multicolumn{2}{|r|}{ IJKLMNO } \\
\hline 23 & 93 HT - 28* & \multicolumn{2}{|r|}{ IJKLMNO } \\
\hline 24 & 93 HD - 14* & \multicolumn{2}{|r|}{ JKLMNO } \\
\hline 25 & $\mathrm{AG}-122 * *$ & \multicolumn{2}{|r|}{ JKLMNO } \\
\hline 26 & 92 HD - 04* & \multicolumn{2}{|r|}{ KLMNO } \\
\hline 27 & CMS - 455* & \multicolumn{2}{|r|}{ LMNO } \\
\hline 28 & 93 HD - 05* & \multicolumn{2}{|r|}{ MNO } \\
\hline 29 & $93 \mathrm{HD}-01^{*}$ & \multicolumn{2}{|l|}{07.94} \\
\hline 30 & 93 HT $-27^{*}$ & \multicolumn{2}{|l|}{07.67} \\
\hline 31 & CATETO - SL**** & 07.58 & $\mathrm{O}$ \\
\hline
\end{tabular}

* QPM **Commercial *** Susceptible check **** Resistance check

${ }^{1}$ Means followed by the same letter do not differ significantly at $a=0.05$, according to the Least Significant Difference Test.

${ }^{2}$ C.V. $=6.16 \% ; S=0.328$ and $\mathrm{LSD}=0.98$ 
result was that eight QPM lines had an IS mean lower than that from the commercial hybrids; however, another group of QPM had an IS similar to the susceptible control. The mean IS of the commercial hybrids stayed in between the resistant and the susceptible. The discovery that some QPM had an IS very close to the susceptible control, the IAC 1- O2 IV (a soft endosperm grain corn), is a strong evidence that there is genetic variability within QPM genotypes for resistance to insect attack. This observation opens the possibility to increase the resistance to insect attack by means of specific selection for resistance, since this trait was not included in the breeding process of the QPM hybrids tested. Also we believe in the possibility to develop QPM commercial hybrids with resistance to stored grain insects in levels compatible with those of the normal endosperm commercial hybrids. It should also be mentioned here that some of these QPM hybrids have yielded as much grain as some of the commercial hybrids tested (Relatório, 1994). Many authors have attempted to explain the genetic resistance in corn grain to maize weevil based on the chemical composition of the grain. Singh and MacCain (1963) found a significant positive correlation between sugar content and field infestation, and a negative correlation between hardness of the grain and susceptibility.

It was suggested (Resistência 1966-67) that chemical composition of the grains could be one of the important aspects determining the genetic resistance. LeCato and Arbogast (1974) noted that higher levels of Lysine and Tryptophan in Opaque-2 and Flowry-2 hybrids decreased the S. zeamais rate of reproduction. Whitney (1973) observed that vitreum endosperm contributed to resistance in corn. Schoonhoven et al. (1972) concluded that resistance was due to a mechanical barrier formed by the pericarp rather than the one caused by endosperm. Glover et al. (1975) reported many mutants in maize (Zea mays L.) that produce striking differences in textural properties, form and amount of endosperm. Several mutants influence gelatinization, starch granule digestibility, and carbohydrate storage products, such as amylose, amylopectin, watersoluble polysaccharide and sugars. King (1978) presents a list of genes that can cause changes in the endosperm through the production of chemical compounds. Some more recent research on resistance to maize weevil in corn grain (Serratos et al. 1987, 1993; Classen et al. 1990) has discovered that phenolic acids content, mainly in the form of (E)-ferulic acid, found 90\% concentrated in the pericarp, testa, and aleurone layer of the seed, play a very important role in suppressing weevil development, most possibly due to antibiosis effect.

The results observed in this research agree with those reported by Arnason et al. (1993) when they studied one group of QPM genotypes in relation to maize weevil resistance. The ultimate conclusion possible to draw from this research is the discovery of a group of QPM corn hybrids and lines that carry genes for resistance to the maize weevil, S. zeamais. It can also be said that the QPM corn is not necessarily, or not always, more susceptible to weevil damage than is the normal endosperm type of corn.

\section{Acknowledgments}

We thank Mr. Frederico V. O. Avelar, Technician of the Stored Grain Pest Research Laboratory for his assistance in collection of data. This work was supported in part by the Ministry of Agriculture, EMBRAPA/National Corn and Sorghum Research Center, Sete Lagoas, MG, Brazil. 


\section{Literature Cited}

ARNASON, J. T.; LAMBERT, J. D. H.; GALE, J.; MIHM, J.; BJARNASON, M.; JEWELL, D.; SERRATOS, J. A.; FREGEAU-REID, J.; PIETRZAK, L. Is quality protein maize more susceptible than the normal lines to attack by the maize weevil Sitophilus zeamais? Postharvest Biology and Technology, Amsterdam, v. 2, p. 349-358, 1993.

CLASSEN, D.; ARNASON, J. T.; SERRATOS, J. A.; LAMBERT, J. D. H.; NOZZOLILLO, C.; PHILOGENE, B. J. R. Correlation of phenolic acid content of maize to resistance to Sitophilus zeamais, the maize weevil, in COMMIT's collections. Journal of Chemical Ecology, New York, v.16, p. 301-315, 1990.

DIMLER, R. J. Report on kernel structure and wet milling of high lysine corn. In: HIGH LYSINE CORN CONFERENCE, 1966, Purdue University. Proceedings... Washington, D.C.: Corn Refiners Association, 1966. p. 121-127.

DOBIE, P. Laboratory assessment of the inherent susceptibility of maize lines to post-harvest infestation by Sitophilus zeamais Motschulsky. (Coleoptera: Curculionidae). Journal Stored Products Research, Oxford, v. 10, p. 183-197, 1974.

GENEL, M. R. Infestacion de campo por insetos de granos almacenados. Agricultura Técnica en México, México, D.C., v. 10, p. 32-40, 1960.

GLOVER, D. V.; CRANE, P. L.; MISRA, P. S.; MERTZ, E. T. Genetics of endosperm mutants in maize as related to protein quality and quantity. In: CIMMYT-PURDUE SYMPOSIUM ON PROTEIN QUALITY ON MAIZE, 1972, El Batan, Mexico. High-quality protein maize: proceedings. Stroudsburg: Dowden, Hutdhing \& Ross, 1975. p. 228-240.
GOMES, H. S.; SANTOS, J. P. Infestacion y dano del Sitophilus zeamais en diez genotipos de maiz. Revista Colombiana de Entomologia, Santafe de Bogota, v. 19, n. 1, p. 6-9, 1993.

HASTEAD, D. G. H. The rice weevil, Sitophilus oryzae (L.) and Sitophilus zeamais, Motschulsky. Identification and synonymy. Tropical Stored Products Information, Berks, v.5, p. 177-179, 1962.

IRABAGON, T. A. Rice weevil damage to stored corn. Journal of Economic Entomology, College Park, v. 52, p.1130-1136, 1959.

KING, R. C. (Ed.). Handbook of genetics. New York: Plenum Press, 1978. 631 p.

KOURA, A. and EL-HALFAWAY, M. The susceptibility of certain Egyptian lines of maize (Zea mays) to infestation with rice weevil, Sitophilus oryzae L., the lesser grain borer, Rhizoperta dominica $\mathrm{F}$., and the host preference of these insects. Agricultural Research Review, Cairo, v. 45, p. 49-55, 1967.

LECATO, G. L.; ARBOGAST, R. T. Multiplication by stored-product Coleoptera on high lysine corn. Journal of the Kansas Entomological Society, Lawrence, v. 47, p. 161165, 1974.

MERTZ, E. T.; BATES, L. S.; NELSON, O. E. Mutant gene that changes protein composition and increases lysine content of maize endosperm. Science, Washington, v. 145, p. 279-280, 1964.

ORTEGA, A. G.; LEON, D. E.; GRANDOS, G.; VASAL, S. K. Disease - insect interaction in quality protein maize. In: CIMMYT-PURDUE SYMPOSIUM ON PROTEIN QUALITY ON MAIZE, 1972, El Batan, Mexico. High-quality protein maize: proceedings. Stroudsburg: Dowden, Hutchinson \& Ross, 1975. p. 173-192. 
RELATÓRIO TÉCNICO ANUAL DO CENTRO NACIONAL DE PESQUISA DE MILHO E SORGO. 1992-1993, Sete Lagoas: EMBRAPACNPMS, 1994. 342 p.

RESISTENCIA de razas del maiz al gorgojo. Noticero del CIMMYT. México, v. 2, p. 3, 1966/ 67.

ROSSETTO, C. J. Resistência do milho as pragas da espiga, Helicoverpa zea (Boddie), Sitophilus oryzae (L.). I. Oviposition, immature mortality and size of adults. Annals of the Entomological Society of America, College Park, v. 55, p. 678-685, 1972.

SANTOS, J. P. A brazilian corn germoplasm collection screened for resistance to Sitophilus zeamais Motschulsky (Coleoptera: Curculionidae) and Sitotroga cerealella (Olivier) (Lepidoptera: Gelechiidae). 1977. 184 f. Thesis (Master of Science) - Purdue University; West Lafayette.

SANTOS, J. P.; FOSTER, J. E. Mecanismos de resistência do grão de milho ao gorgulho. Pesquisa Agropecuaria Brasileira, Brasilia, DF, v. 18, p. 1059-1063, 1983.

SANTOS, J. P.; FONTES, R. A. Armazenamento e Controle de insetos no milho estocado na propriedade agrícola. Informe Agropecuário. Belo Horizonte, v. 14, n. 164, p. 40-45, 1990.

SANTOS J. P.; MAIA, J. D. G.; CRUZ, I. Efeito da infestação pelo gorgulho (Sitophilus zeamais) e a traca (Sitotroga cerealella) sobre a germinação de sementes de milho. Pesquisa Agropecuária Brasileira, Brasília, DF, v. 25, n. 12, p.1687-1692, 1990.
SCHOONHOVEN, A. V.; HORBER, E.; MILLS, R. B.; WASSON, C. E. Resistance in corn kernel to the maize weevil. Entomological Society of America North Central Branch Proceedings, v.27, p.108-110, 1972.

SERRATOS, J. A.; ARNASON, J. T.; NOZZOLILLO, C.; LAMBERT, J. D. H.; PHILOGENE, B. J. R.; DAVIDSON, K.; PEACOCK, L.; ATKINSON, J.; MORAND, P. Contributions of phenolics antefeedants to resistance of maize to the maize weevil, Sitophilus zeamais. Journal of Chemical Ecology, New York, v.13, p. 751-761, 1987.

SERRATOS, J. A.; BLANCO-LABRA, B.; MIHM, J. A.; PIETRZAK, L.; ARNASON, J. T. Generation mean analysis of compounds in maize grain and susceptibility to maize weevil Sitophilus zeamais infestation. Canadian Journal of Botany, Ottawa, v. 71, p.1176-1181, 1993.

SINGH, S. R.; MCCAIN, F. S. Relationship of some nutritional properties of the corn kernel to weevil infestation. Crop Science, Madison, v. 3, p. 259-261, 1963.

VILELA, H.; SILVA, J. F. C.;VILELA, D.; SILVESTRE, J. R. A. Alterações do valor nutritivo do grão de milho (Zea mays) durante o armazenamento. Revista da Sociedade Brasileira de Zootecnia, Viçosa, v. 17, p. 428-433, 1988.

WHEATLEY, P. E. Relative susceptibility of maize varieties. Tropical Stored Product Information. London, n. 25, p. 16-18, 1973.

WHITNEY, W. K. Control of insects by nonchemical methods. Tropical Stored Products Information. London, v. 25, p. 20-21, 1973. 